\title{
'A pretty decent sort of bloke': Towards the quest for an Australian Jesus
}

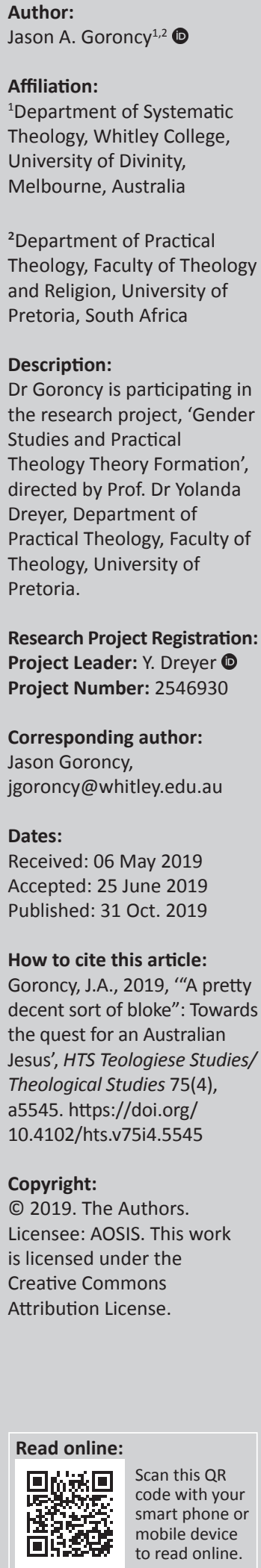

From many Aboriginal elders, such as Tjangika Napaltjani, Bob Williams and Djiniyini Gondarra, to painters, such as Arthur Boyd, Pro Hart and John Forrester-Clack, from historians, such as Manning Clark, and poets, such as Maureen Watson, Francis Webb and Henry Lawson, to celebrated novelists, such as Joseph Furphy, Patrick White and Tim Winton, the figure of Jesus has occupied an endearing and idiosyncratic place in the Australian imagination. It is evidence enough that 'Australians have been anticlerical and antichurch, but rarely antiJesus' (Piggin 2000:163). But which Jesus? In what follows, I seek to listen to what some Australians make of Jesus, and to consider some theological implications of their contributions for the enduring quest for an Australian Jesus

Keywords: Aboriginal Australians; art; Australia; Christology; culture; Jesus; land; myth; religion; symbols.

\section{Who is this man? Whose is this man? Questions that will not go away}

Aboriginal Australians have seen in Jesus 'the life-giving Creator Spirit [taking on] human form' (The Rainbow Spirit Elders 2012:59) and the embodiment of the spiritual sapience of their ancestors. White colonists have commonly identified him as 'a fellow-struggler within the Labour movement, and as a fellow-sufferer in the greatest of our national calamities, our disasters and our wars' (Piggin 2000:150-151). From the journalist and novelist William Lane in the 19th century, to songwriters Kev Carmody and Paul Kelly in the 21st century, there is a lively tradition in Australia of seeing Jesus as both a political underdog himself and as 'the champion of the underdog' (Zaunbrecher 1980:312; cf. O'Farrell 1962:141-142), as a kind of official for some obscure and very small trade union that stands with the underside. At the turn of the last century, William Lane, Bill McNamara and the poet Victor Daley (see, e.g., Daley 1947:78) spoke of Christ as an anti-capitalist champion of the labour movement, and the much-celebrated Henry Lawson (1984) wrote, in the Worker in 1894, that:
Christ is coming once again ...
Not humble, meek, and lowly, as he came in days of old,
But with hatred, retribution for the worshippers of gold!
And the roll of battle music and the steady tramp of feet
Sound for ever in the thunder and the rattle of the street! (p. 407)

\section{Jesus and religion}

While there remain pressing questions here about just how much Lawson and others represent the coloniser's attempt to whitewash the misappropriation of Indigenous land and so disregard Aboriginal sovereignty - theirs is a Jesus who looks quite like a white squatter ${ }^{1}-$ what is obvious is that theirs is a Jesus far removed from the carefully formulated Greek dogma of the Church and the ephemeral heights of heaven. This is Comrade Jesus who hangs out (Lawson 1984):

\footnotetext{
Where the needle-woman toils

Through the night with hand and brain,

Till the sickly daylight shudders like a spectre at the pain -

Till her eyes seem to crawl,

And her brain seems to creep -

And her limbs are all a-tremble for the want of rest and sleep! (p. 406)
} 1.This image, and variations of it, persisted in the Australian imagination until World War II, after which time it began to be both
questioned and accompanied by other images, initially by those carried by migrants from Eastern Europe who arrived bearing different
religious traditions and marked by different experiences. This gave rise to images of Jesus as a refugee and of Jesus as a Jew, images
that implicitly questioned the Jesus-as-a-strong-white-squatter tradition. The repertoire of images further expanded during the following decades to include images of female and of Asian Jesuses. 
Whatever those churchies may think, we know, wrote the Australian poet Edwin James Brady, that the real Jesus, the man of the bush and of that great sermon on the hill, is a mate, and the true Christian is one who (Brady n.d.):

[M]ay have no orthodox creed, but he [sic] is one who has practised towards his mates those precepts that were given by the Nazarene to humanity. He believes in mateship, and he loves his neighbour more than he does himself. He is not religious, but he is Christian enough to act square, and Christ-like enough to feel righteous indignation at wrong and injustice wherever he may see it or hear of it.

\section{So Marian Zaunbrecher (1979) wrote:}

True religion, to the writers of the 1890s, was a matter of right action and not right belief. Religion was a matter of doing the right thing - of providing succour and food for a starving mate, of helping a neighbour fight a bushfire, of sharing a beer on a hot day, of comforting a mate's widow, of finding pasture for one's bullocks and of sharing a windfall. It was a matter of being a true mate.

These values were crystallised in the coming of socialism and unionism to the outback. Unionism was everything that mateship meant to a man. As a result, unionism became the religion of much of the literature of the 1890s. However, mateship - socialism - unionism was not a consciously held substitute for religion but a subtle extension of the meaning of Christianity to the man in the bush. This was what the Christian gospel was all about; this was the message of Jesus in his sermon on the mount. (p. 112)

True religion, it is assumed, also lies in the Ritschlian and Harnackian idea of the brotherhood of man, a commitment expressed in one of Banjo Paterson's old bush songs, 'My Religion' (Paterson 1905):

Let Romanists all at the Confessional kneel,

Let the Jew with disgust turn from it,

Let the mighty Crown Prelate in Church pander zeal,

Let the Mussulman worship Mahomet.

From all these I differ - truly wise is my plan,

With my doctrine, perhaps, you'll agree,

To be upright and downright and act like a man,

That's the religion for me.

I will go to no Church and to no house of Prayer

To see a white shirt on a preacher.

And in no Courthouse on a book will I swear

To injure a poor fellow-creature.

For parsons and preachers are all a mere joke,

Their hands must be greased by a fee;

But with the poor toiler to share your last 'toke',

That's the religion for me.

Let Psalm-singing Churchmen and Lutheran sing,

They can't deceive God with their blarney;

They might just as well dance the Highland Fling,

Or sing the fair fame of Kate Kearney.

But let man unto man like brethren act,

My doctrine this suits to a $\mathrm{T}$,

The heart that can feel for the woes of another,

Oh, that's the religion for me. (pp. 127-128)

2.'Toke' is a slang word for bread
The Jesus of the white Australian imagination is certainly more at home with Paterson's religion than with that of the official church. This Jesus is the kind of bloke who, as David Millikan put it in The Sunburnt Soul, is deeply involved with humanity, loves to party, enjoys a beer, feels comfortable around women, is fond of kids, hates hypocrites, gets grumpy with religious types and reckons that religious customs should be adjusted to meet human needs (see Millikan 1981:111). Those in power become 'very annoyed' (Clark 1990:126) when they hear of such a Jesus, testimony to whom from the outside, as it were, serves in many ways as an act of resistance to the Church's authorised portrait and so, inadvertently, opens up a more public place for spiritualities of disruption inspired by Jesus.

What to do with the religion that is associated with him, even among religious observers, remains, therefore, a question met by awkwardness and confusion, and with a form of spirituality quite disconnected from life's normal routines. One is reminded of Patrick White's description, in The Tree of Man, of Stan Parker whom 'no one could sink a post hole like, or fell a tree, or shoe a horse at a pinch, with improvised tools, in shorter time', and of his wife Amy, 'a bright, industrious young woman' who used to shake dusters off the veranda and sit on logs to shell peas, and of their experience of going to church (White 1956):

Halfway to Bangalay a church had been built, for people of the surrounding district to keep their Sundays in. And some did. Prayers were read, and the lurching hymns were sung. You could not call it worship so much as an act of decent behaviour, at least for most. Amy Parker went out of respect for the gentler moments of her up-bringing. And she liked to sing a sad hymn. If she ventured beyond acts, it was to consider the remoteness of her husband's shoulder. What does Stan, in his Sunday clothes, think of in church? she wondered, brushing from her face the flies and a shadow of resentment. She resented some personal experience enclosed in him, subtler than her own yearning occasioned by the sad hymns. Her voice had a slightly voluptuous curve. She kept a bottle of scent, that she shook up and sprinkled on her front for Sunday church, and that scented the hot horsehair and the dust. As she sang through her rather moist lips, she was glossy to look at, her substance was indisputable. But you could not put your finger on what there was about Stan.

The man himself could not have told. He was confused, because his wife was watching, and the words of worship expected too much. His body too, of which he was partly ashamed, made him kneel with an awkwardness that he did not connect with humility. But he was humbler. When he failed to rise to the heights of objective prayer he would examine himself, or the grain of the pew, finding such flaws in each that there was little hope of correction. At times, though, peace did descend, in a champing of horses' bits at a fence outside, in some word that suddenly lit, in birds bringing straws to build nests under the eaves, in words bearing promises, which could perhaps have been the grace of God. (p. 64)

Perhaps, Amy's and Stan's faith might have been better served had they been encouraged to look for Jesus by the post hole, or on the veranda while shelling peas - to look for 
him where he is to be found, as the Gospels suggest, to meet him unawares at the point where one has, like Stan, 'more or less resigned' oneself 'to that state of god-lessness he had chosen when he vomited God out of his system and choked off any regurgitative craving for forgiveness' (White 1956:356; cf. Kramer 1974:269-283).

\section{Jesus modified: Reg Mombassa}

The sense of the good-humoured larrikin Jesus, so prominent in the 19th century, continues to find expression in the work of a significant number of contemporary Australian artists. It is, for example, the kind of playful disruption present in the work of the Sydney artist Elaine Campaner who, in her 1999 series 'The New Testament as understood by small children', costumed and posed Barbie dolls as characters from Bible stories. More well known is Chris O'Doherty's work, especially his 'The Australian Jesus Series' and his 'Mambo Theology' works. O'Doherty, who goes by the pseudonym Reg Mombassa, does not call himself a 'believer', but in these works he certainly appears to have caught something of the gospel's own portrait of the dissident from Galilee. His drawing on more traditional Christian images, such as the way that his 'Temptation in the Light Industrial Garden of Eden' (1998) plays on Lucas Cranach's 'Adam and Eve' (1526), further betrays his debt to that Christian tradition which much of his own work is parasitic upon, honours and extends, even while overturning it in a kind of holy irreverence. One example of such is his 2016 drawing, 'Australian Jesus stripped bare', the tenth panel of his Stations of the Cross and which was a finalist in the 2018 Blake Prize. The work depicts a wooded, cruciform and transgendered Jesus who is on the move by wheels across a devastated post-industrial landscape and who is being stripped bare by ugly and violent claws. The 'Australian Jesus stripped bare', like Zara Sullivan's photograph 'Sheezus' (2017), which was also shortlisted as a finalist in the same year's Blake Prize, asks challenging questions about sexual orientation and gender justice, and about how gender itself may or may not be a defining characteristic of traditional claims vis-á-vis the person of Jesus even while gender and Jesus remain properly relevant to each other. About this work, O'Doherty (2018) writes:

In this picture the Australian Jesus figure is transgender in that he/she has a wooden penis and wooden breasts. The Australian part of the Jesus title is a reference to the widely practiced habit of making regional modifications or adaptations of the Jesus story. These modifications also often extended to sexual orientation subcultures and popular culture movements as well as to certain localities or racial groups. The clawed arms stripping the garments from the Jesus figure are not animals but the various representatives of the cruel and unjust patriarchal authorities that have tormented and suppressed women, homosexuals and the members of religious political and racial minorities throughout human history. The burnt out industrial landscape is another reference to the failings of this patriarchal warrior hero alpha male paradigm that has governed human affairs so poorly and so disastrously since the dawn of our recorded history. (p. 40)
My own sense is that, by and large, Australians - even church-going Australians, and especially since World War I - are deeply disappointed with religion and with the failure of religious institutions to be the bearers of promised salvation, and/or to be with Christ where Christ is - in hell. Rather than embodying lives characterised by the kind of riskiness and humility that Christian communities claim is at the centre of God's message of love for others, many have displayed an unyielding proclivity to stubbornly invest in their own self-preservation. By doing so, the Christian community risks not being contemporary with Christ. Dietrich Bonhoeffer, writing from his Tegel Prison cell in 1944, reminded us: 'The church is church only when it is there for others' (Bonhoeffer 2010:503). Many Australians have judged fairly that the church has not heeded Bonhoeffer's call; that the church has in fact betrayed Jesus at this point.

\section{Jesus the counter-hypocrite: Suzie Marston and Maureen Watson}

That sense of betrayal and of profound disappointment is expressed in Suzie Marston's Blake Prize-winning work, 'In Mockery of Christ' (1982). The painting, which betrays echoes of work by Mexican feminists and surrealist painters, such as Leonora Carrington, Remedios Varo and, especially, Frida Kahlo, was Marston's response to a recession that hit hard the Illawarra steel and coal mining district in southern New South Wales in 1982. Rapidly-growing unemployment, particularly among those aged between 18 and 24 years, and 50 and 59 years, led to the rise of a union-led activism of which Marston found herself a part. As she later put it in conversation with the celebrated art historian Rosemary Crumlin (2011):

Many people lost their jobs and I saw no justice for them and I wondered if there was going to be any divine intervention and I did not see any ... All the pageantry of the church, all of the icons failed these people, and those who held the higher moral ground should have been there for them but weren't. No one came to help these people; they were abandoned and I saw their faces at the gates. There was no comeback for them and they languished by themselves in deep despair. (p. 106)

Crumlin (2011) suggests that:

Marston's response was to paint this triptych ... Her anger and disillusion were directed more particularly to Christians 'who hold the higher moral ground' and to the institution of the Church: both stood silently by when they could and should have stood with the jobless. (p. 106)

Marston's choice of the triptych form ought not be lost on us either, for it serves here as a kind of anamnesis, a recollection, of the altarpieces that mark Early Renaissance art and which typically depict scenes from Christ's life, suffering and death. In Marston's work, however, the only altar it adorns, as it were, is 'an altar of protest' (Crumlin 2011:106). So Crumlin (2011):

In the centre panel is a young man tied to the cross. He could easily be any Illawarra lad who marched against oppression and 
who suffered injustice. He is alone, watched impassively by a crowd of woolly sheep. The background is the Illawarra landscape. The woman in the left panel has her arm around a sheep-man. He wears the bow tie of the art dealer. Two more sheep turn in their kitchen chairs to grin-grimace at the viewer. The woman on the right holds a sheep; another looks out. No one engages in the drama imaged in the centre panel. (p. 106)

Two years after completing 'In Mockery of Christ', Marston produced another image, an untitled pastel on paper, in which Jesus reappears, again bound to a cross but this time as a naked woman. The work reads as something of a mixed report on women's social liberation, identified with Jesus who himself - or herself, as the case is here - represents a movement of freedom from social and other expectations that mark a life suppressed. In this later work, one detects a kind of homage to Jesus. The mocking, for Marston, denotes the ways that the Church has failed to be the Body of Christ. It is indeed particularly difficult to avoid being the scapegoat when you choose to locate yourself on a higher moral ground and not, as in the figure in the first and third panels of Marstons's 'In Mockery' of Christ, among the sheep.

The sense of profound disappointment, bewilderment and even anger at the Church has not, however, translated into analogous feelings about Jesus. It seems that many Australians feel kind of sorry for Jesus - sorry that he has been claimed and prostituted by this tax-dodging and paedophile-producing franchise called 'the Church'. So Maureen Watson's poem, 'Memo to J.C.' (Watson 1994):

When you were down here JC and walked this earth, You were a pretty decent sort of bloke,

Although you never owned nothing, but the clothes on your back, And you were always walking round, broke.

But you could talk to people, and you didn't have to judge,

You didn't mind helping the down and out

But these fellows preaching now in your Holy name,

Just what are they on about?

Didn't you tell these fellows to do other things,

Besides all that preaching and praying?

Well, listen, JC, there's things ought to be said,

And I might as well get on with the saying.

Didn't you tell them 'don't judge your fellow man'

And 'love ye one another'

And 'not put your faith in worldly goods'.

Well, you should see the goods that they got, brother!

They got great big buildings and works of art,

And millions of dollars in real estate,

They got no time to care about human beings,

They forgot what you told 'em, mate;

Things like, 'Whatever ye do to the least of my brothers,

This ye do also unto me'.

Yeah, well these people who are using your good name,

They're abusing it, JC,

But there's people still living the way you lived,

And still copping the hypocrisy, racism and hate,

Getting crucified by the fat cats, too,

But they don't call us religious, mate.

Tho' we got the same basic values that you lived by,

Sharin' and carin' about each other,

And the bread and the wine that you passed around,
Well, we're still doing that, brother.

Yeah, we share our food and drink and shelter,

Our grief, our happiness, our hopes and plans,

But they don't call us 'Followers of Jesus',

They call us black fellas, man.

But if you're still offering your hand in forgiveness

To the one who's done wrong, and is sorry,

I reckon we'll meet up later on,

And I got no cause to worry.

Just don't seem right somehow that all the good you did,

That people preach, not practise, what you said,

I wonder, if it all died with you, that day on the cross,

And if it just never got raised from the dead. (pp. 222-223)

\section{Whatever happened to the tall man on the seashore?: Athol Gill}

But who is this 'pretty decent sort of bloke' who was 'always walking round, broke', who could 'talk to people' and who 'didn't have to judge'? Where has he gone? Strangely, Australian theologians have, by and large, been quite uninterested in pursuing the question of what an Australian Jesus might be like, preferring instead to stay with the (white) English, or American, versions. Among the very few exceptions to this was Athol Gill. ${ }^{3}$ In his research and teaching, Gill, who had an uneasy relationship with the church, was particularly committed to noticing those who live on life's margins, observing Christ's continued association with the 'nobodies of society', the 'little people of Christ' (Gill 1990:168) who remain largely hidden in the suburbs of Australia's cities, and who are largely absent from Australia's churches. Jesus, Gill argued, stood with, and pronounced God's blessing on, not the middle and upper classes who populate most of the church, but rather with 'the poor', and he 'demonstrated his presence with the persecuted', inviting (only?) 'the outcasts and marginalised people of society to join him in the kingdom of God' (Gill 1990:137). Gill constantly sought ways to embody this message in his own life and work too, a fact evidenced most publicly in the formation of two inner-city faith communities - the House of Freedom in Brisbane, and the House of the Gentle Bunyip in Melbourne - which were both marked by service to and with the poor, the homeless, the aged, the mentally ill and disadvantaged children.

Throughout his life, Gill was seeking to find again the man who had so fascinated him in his childhood and who he heard about at his Methodist Sunday School: The 'man with a long robe and a beard [who] had captured another young boy's heart'. Gill's work, it seems, was driven by the quest to answer the question: 'What had happened to that tall man on the seashore?' (Gill 1993:11). His experience at theological college did not help him answer that question but left Jesus in the past so that he 'seemed a long distance away' (Gill 1993:12). But as Gill studied the Gospels, refusing to leave Jesus locked in the pages of history but instead taking seriously Bonhoeffer's question, 'Who is Jesus Christ for us today?', 'gradually', Gill (1993) wrote:

3.See also Rees (1999) 
[T] he stranger from Galilee began to introduce me to his friends among the little people of Australian society ... I came to see that his strangeness was not so much one of time but of perspectives. (pp. 13-14)

Gill believed that the 'tall man on the seashore' continues to call people to 'leave everything to follow him' (Gill 1993:3) an act he describes, following Johann Baptist Metz, as, inescapably, a kind of 'class treason' (Gill 1990:28; Metz 1981:14-16). This call - the demands associated with which are 'unconditional' and 'all embracing' (Gill 1990:25) - is always a call away from individualism and into community, a community that embodies the possibility of Jesus' continuing life in the world today. Gill had all but given up on the possibility of the established church ever fulfilling such a role. In this regard, he was a true anabaptist. At the House of the Gentle Bunyip, he developed a detailed document outlining the 'Rule of the Community'. It acknowledged that Jesus is the centre of the community's common life, and that the community must therefore 'seek to live in openness to the future' and resist the temptation to 'take on a structure, or even a confession of faith, which will bind it to the present and ultimately bury it in the past' (Gill 1984:14-15), where it, like the Jesus of the church, is rendered all but dead and irrelevant.

\section{The flesh made Word: Nick Cave}

A more sophisticated tribute to Jesus is evident in the work of musician, screenwriter and author Nick Cave. Cave once self-identified as a 'Christian' - he mixed with Anglicans in his youth, singing in the Anglican Church choir in Wangaratta (see Johnston 1996:25-31) - but as he confesses in his recording, 'The Flesh Made Word' (Cave 2000):

The God I heard preached about there seemed remote, and alien, and uncertain. So I sat in the stalls, in my crimson cassock, while rogue thoughts oozed beneath the bolted door of my imagination.

Now Cave believes in 'God in spite of religion, not because of it' (Cocker and Cave 2010). 'Religion', he says, is (Bartlett 2004):

$[A] n$ American thing, in which the name of God has been hijacked by a gang of psychopaths and bullies and homophobes, and the name of God has been used for their own twisted agendas.

'I'm not religious, and I'm not a Christian', says Cave (Payne 2010):

[B]ut I do reserve the right to believe in the possibility of a god. It's kind of defending the indefensible, though; I'm critical of what religions are becoming, the more destructive they're becoming. But I think as an artist, particularly, it's a necessary part of what I do, that there is some divine element going on within my songs.

While Lyn McCredden insists, understandably but contestably, that 'Nick Cave is not a theologian' (McCredden 2009:167), much of Cave's work is explicitly a conversation with Christian theology, especially with the Christian Scriptures, which he reads idiosyncratically from the vista of one who has rejected the church and is fascinated with Jesus. The church, Cave believes, represents those who promote 'the established order of things' and who crush and suffocate the human imagination in law, and thereby kill God who is 'imagination taken flight' (Cave 2000). The church eschews that imagination and so denies the unbound, eschatological and interruptive character of Jesus, which is 'at times terrible, irrational, incendiary and beautiful; in short, Godlike' (Cave 2000). Cave associates the church with the scribes and pharisees who, in the Second Testament, stand against Jesus. They are those (Cave 2000):

$[D]$ ull, small-minded scholars of religious law who dogged his every move. Christ saw them as enemies of the imagination, who actively blocked the spiritual flight of the people, and kept them bogged down with theological nitpicking, intellectualism, and law. What was Christ's great bugbear, and what has sat like dung in the doorway of the Christian church ever since, was the Pharisees' preoccupation with the law in preference to the logos.

Cave's Jesus is a man condemned, 'a gilled Jesus shivering on a fisherman's hook' (Nick Cave and the Bad Seeds 2001). It is difficult to overlook the association here between fishermen and the church.

McCredden rightly observes Cave's concern for the sacred that is 'deeply enmeshed in the human dimensions of flesh, erotics and violence. The sacred - the holy, divine, hierophanic, epiphanic - and the profane do not stand apart in his work', she writes (McCredden 2009):

$[B]$ ut are in dynamic and conflicting conjunction, creating a sprawling, unsystematic and confrontational dialogue with divine forces which may or may not be 'there'. Institutional religion does not fare well in his lyrics, but nor is it ignored. What we find stamped across his songs, over and over, is the dark, lonely figure of a man caught up in desire for a divine source or balm. (p. 167)

Cave seeks redemption - 'all down my veins my heartstrings call' (Nick Cave and the Bad Seeds 1997) - and among his main landing places on that search is a Jesus manifested in endless forms, who is always more of a question than he ever is an answer, and who is the possibility that God is otherwise than the 'brutal', 'jealous', 'merciless', 'cruel', 'rancorous' and 'despotic' God we meet in the Hebrew Bible (Cave 2000). In 'that eerie figure that moves through the Gospels' and whose voice is 'softer, sadder, [and] more introspective', Cave seeks 'a chance to redefine [his] relationship with the world'. That redefinition, that new orientation, is, Cave believes, birthed of the 'flight of the imagination' - God (Cave 2000).

In The Boatman's Call, an album that 'teeters between eros and agape' (Eaglestone 2009:148), Cave describes Jesus as 'a man who spoke wonders though I've never met him', and then cites Jesus's promise: 'He who seeks finds and who knocks will be let in' (Nick Cave and the Bad Seeds 1997). In his first novel, And the Ass Saw the Angel (1989), Cave explores and 
plays with the possibility of divine presence in the character of Euchrid, the mad, hermetic and mute boy whose imagination God fills until, 'like a blocked pipe', Euchrid bursts. Just like Jesus. Indeed, for Cave, 'Euchrid is Jesus struck dumb, he is the blocked artist, he is internalized imagination become madness' (Cave 2000). Yes, Euchrid represents a God who has fallen silent, only later to embed himself into the human race through Jesus Christ, and to suffer with them. And yes, the divine's association with madness is as biblical as it is expressed in Cave's work, or in something like Rolf de Heer's film Bad Boy Bubby (1993). But Euchrid is a reminder too that (Turner 2014):

$[F]$ or Cave, divine presence must hold the potential for both life-giving and ecstatic spirit and violent ecstatic despair. To separate these two forces is to deny divinity altogether and to kill the wild, erratic, erotic and creative potential of the human imagination - God. (pp. 193-194)

Readers and listeners might wonder also if Cave senses something of Jesus within himself - within his own aching desires. But this is not named, nor perhaps desired.

Born 5 years before Cave, and in the same year as Marston, the controversial Tasmanian artist Rodney Pople also exploits religious symbols for their proximity to human eroticism. His paintings 'High Altar' (2011) and 'Dusk' (2012) represent just two such examples. In Pople's 'Shoot Up for Jesus' (2013), sex is the drug of choice, mockingly ordained 'before God'. The association of Jesus with drugs is also evident in Adam James K's 2012 portrait of his friend, the talented Adam Cullen, who died that same year (see Jensen 2014). Originally, it was James K's intention to paint Cullen as Australia's most loved and notorious bushranger Ned Kelly, but Cullen convinced him that it would be more surprising to show his vulnerability and his suffering poor health, and that the figure most widely associated with such human experiences - and with the fact that life, in Cullen's own words, is 'a constant bloody drama' (Fortescue 2015) is Jesus, depicted in $\mathrm{K}^{\prime}$ s portrait as an isolated and strange figure, a loner who identifies, in Cave's words, with 'a young girl full of forbidden energy flickering in the gloom', with 'a drug addict lying on [his/her] back in a Tijuana hotel room', with the 'African doctor harvesting tear ducts', with 'an old man by the fire' and with 'the mist rolling off the sea' (Nick Cave and the Bad Seeds 2016).

\section{The Word made land: Julie Dowling}

The final artist I will consider in this essay is Julie Dowling. Dowling is a Badimia woman from Subiaco in Western Australia with roots in Russian and Jewish culture, and in Irish and Scottish Roman Catholicism. Her work draws on a diverse range of sources from European portraiture, Christian and Indigenous Australian iconography, and public street art, and is marked by political and justice themes related especially to colonial occupation and the brutal government policies of intervention and assimilation (see McGrath 2002:37-40). Dowling and her twin sister Carol were the first members of their family to be recognised in the first Australian census to include Aboriginal people, in 1967 (see Jackett 2013:173-175). As the Aboriginal rights activist Sol Bellear put it: 'Before 1967, we weren't counted in the census or anything as people. Dogs and cats and pigs and sheep were counted in Australia before Aboriginal people' (cited in Daley 2017).

As an Aboriginal person, land lies at the heart of Dowling's connection with her ancestors. She is particularly interested in exploring the implications of this with regard to her relationship with her grandmother's (Mary [Mollie]) and great grandmother's (Mary Oliver) country. Symbolically returning her ancestors to land, something that is embodied in her 2002 painting, 'Self-portrait: In Our Country', offers, for Dowling, avenues to both strengthen and contribute to her heritage, and to connect with those who have learnt to walk in the land before us (see Jackett 2013:205-206). As the Aboriginal elder Galarrway Yunupingu put it, 'the land own us' (cited in Perkins and Lynn 1999:x), and Dowling's commitment to helping all Australians to see - to literally 'see' - the truth of that claim, and so their own location, is evident throughout her work. When asked what message she would like to leave for the future, she responded (Bannister \& Dowling 2005):

See that part of country where you're standing right there? I want you to find out who walked it before you did and figure out what totem it is, and look after the bloody totem, thanks ... When you've got no connection to something ... you're basically walking on the world with feather feet, you're not touching it ... Have more connection to your country and then you understand yourself. Which is sort of what universally blackfellas have been saying ever since they met Wudjulas [non-Aboriginal persons].

Elsewhere she writes (Dowling 2006):

Stories of our survival against oppression and the experiences of displacement from our lands are all embedded in the personal and social memories of Aboriginal communities in Australia and are within reach of the imagination of all. (p. 9)

Here, we might recall Jesus' own habit of both calling blind people to see, and of enabling such sight, while offering a critique of those who can see but would not. Traditionally, in Christian theology, this sight is made possible by the Spirit who, through the myriad of creation's gifts, both generates and births Jesus, and makes our seeing him in the world possible.

It has been argued that Aboriginal images of Jesus are fundamentally related to claims about land. There is, for Aboriginal artists (Pattenden 2014):

$[N]$ o sense that Christ resides with God far away in heaven, removed from human and social life. Rather, Christ is alive in the relations ordered by the land as Aboriginal people continue to care for the land and its dreaming as an ongoing presence and activity. (p. 25)

Reflecting on the work of Giga artist Shirley Purdie who works in the Kimberley region and who has produced paintings that reflect the massacre that took place at 
Mistake Creek in 1915, the precise facts around which remain contested, Pattenden (2014) notes:

Christ [Ngambuny] in this region is in the ground, the soil, and the land. Mixed with the blood of suffering, he is the one who carries the mourning and loss, and brings comfort and renewal. His face is found not in any simple likeness, but in an embodied presence in the forms and folds of the land's embrace that sustains ongoing human community. These images express the process whereby an indigenous community sees in the Christian story a means to express their own faith and by implication their one self-representation as the site for divine action. This in turn disorientates the European colonial eye. It brings dizziness to the European eye, used to fixed terms and chronologies, a condition that is welcome in fluid hybrid spaces. (p. 27)

This connection between land, memory, seeing and identity pervades Aboriginal theology and serves to highlight the deep pain caused by colonial invasion. It serves also as a generous invitation to later arrivals to the land now called 'Australia' to see their future as being bound up with attention to such connection. In his essay, 'The Land our Mother, The Church our Mother', Patrick Dodson recalls how in Indigenous cultures 'law' or 'dreaming' provides 'a coherent and all-encapsulating body of truths which govern the whole of life' (Dodson 1988):

'The Dreaming' or 'The Law' includes the past and ongoing activities of creative and life-giving forces which always retain a sense of immanence and transcendence, of the actual and potential. Western understandings of time are beautifully confounded by these concepts. (p. 83)

Dodson's description of 'The Dreaming' echoes that of the Rainbow Spirit Elders, for whom 'The Dreaming' provides the subterranean reality that undergirds and makes possible an entire theology. It is that 'spiritual dimension of reality that has existed from the beginning' (The Rainbow Spirit Elders 2012:xi). It bespeaks of a creation vivified by the Creator Spirit, by Christ. It bespeaks Incarnation, that 'from the beginning, the Rainbow Spirit has been and still is present deep within the land' (The Rainbow Spirit Elders 2012:30). This is a truth borne witness to in a song of the WonguriMandjigai people of North-East Arnhem Land:

Up and up soars the evening Star, hanging there in the sky.

Men watch it, at the place of the Dugong and of the Clouds, and of the Evening Star,

A long way off, at the place of Mist, of Lilies and of the Dugong. The Lotus, the Evening Star, hangs there on its long stalk, held by the Spirits.

It shines on that place of the Shade, on the Dugong place, and on to the Moonlight clay pan ...

The Evening Star is shining, back towards Milingimbi, and over the ‘Wu:lamba people ...

Hanging there in the distance, towards the place of the Dugong, The place of the Eggs, of the Tree-Limbs-Rubbing-Together, and of the Moonlight clay pan ...

Shining on its short stalk, the Evening Star, always there at the clay pan, at the place of the Dugong ...

There, far away, the long string hangs at the place of the Evening Star, the place of Lilies.

Away there at Milingimbi ... at the place of the Full Moon,
Hanging above the head of that 'Wonguri tribesman:

The Evening Star goes down across the camp, among the white gum trees...

Far away, in those places near Milingimbi ...

Goes down among the 'Nurulwulu people, towards the camp and the gum trees,

At the place of the Crocodiles, and of the Evening Star, away towards Milingimbi ...

The Evening Star is going down, the Lotus Flower on its stalk ... Going down among all those western clans ...

It brushes the heads of the uncircumcised people ...

Sinking down in the sky, that Evening Star, the Lotus ...

Shining on to the foreheads of all those headmen ...

On to the heads of all those Sandfly people ...

It sinks there into the place of the white gum trees, at Milingimbi. (Translation by R. M. Berndt, in Berndt 1948:50)

The Rainbow Spirit Elders associate this soaring, shining, visiting, descending energy with a Christ older than the Hebrew nation, unashamed to make home in land and in human culture (see Paulson 2006:310-320), and through whom 'the land and the people are reconciled with the Creator Spirit' (The Rainbow Spirit Elders 2012:69).

Dowling's work realises such a commitment and represents a quest to pursue that conversation with other chapters and icons of the Christian story. This is not an altogether incongruent meeting, for as one Elder put it: 'We always know about Ngapuny [God] but youse mob had to come to tell us about Mary and Jesus' (cited in Crumlin 2011:153). After two centuries, what has been liberating for many Aboriginal - and indeed white - people is that they do not have to 'become a white man to know Jesus Christ' (The Rainbow Spirit Elders 2012:xvii). This serves as a reminder that whether it is the Western Jesus clothed in Greek metaphysics, or it is the African or Asian Jesus always trying to strip off the clothes in which Western missionaries dressed him - as the Malawian theologian Joest Mnemba put it to Western missionaries, 'No longer does our faith depend on your story' (Mnemba 1988:32) - Christology is deeply and inescapably bound up with, and is betrayed by, broader cultural assumptions and political commitments.

Most European missionaries had little regard for the beliefs and practices that are central to the way of life for Aboriginal people and 'actively promoted a European culture as superior'. The white German Jesus carried by the German missionaries to the lands of the Aboriginal peoples never touches the soil, never shares skin, never builds his 'humpy among ours' (The Rainbow Spirit Elders 2012:3). As the Aboriginal poet Oodgeroo Noonuccal (Kath Walker) put it, 'Though baptized and blessed and Bibled/We are still tabooed and libelled' (Walker 1992:61). Even better attempts are marked by what might generously be called mixed success. ${ }^{4}$ A devastating - and more typical - illustration of this narrative is Gordon Syron's painting 'Civilising the Natives' (2009) that depicts Indigenous persons made individuals, forced to abandon their cultural signs as they are marched into a church building flanked by British soldiers in 4.See, for example, Hill (2002). 
bright red uniform, while a black Jesus hangs bleeding on a white cross removed from the Christian symbols of priest and chapel. But the gospel is the story of how 'God camped among us as a human being' and 'became one of us in our land, and became part of our culture' (The Rainbow Spirit Elders 2012:59). This then means for Aboriginal people that 'Christ is an Aboriginal Australian, not an alien or foreign human being whom we cannot know' but 'an Aboriginal person "camping" among us, giving life to our people and [to] our stories' (The Rainbow Spirit Elders 2012:61, 62). Might this have been what Sydney Parkinson, who was, as far as we know, the first European artist to visit Australia, was bearing witness to in his sketch from $1770^{5}$ when he placed a crucifix figure (or is it simply 'a human figure with outstretched arms'? [Smith 2009]) across the chest of an Aboriginal man? This is unlikely (see Banks 1962:53; Smith 1985:28), but the theological questions that now arise from such a work ought not be lost on us. One of the workshop participants from the conversations that took place among a group of Aboriginal leaders in Queensland during the mid1990s summarised the task of developing an Aboriginal Christology in these words (The Rainbow Spirit Elders 2012):

The Jewish people struggled to lift the temple veil that shrouded God as revealed to us in Jesus Christ. We are in the process of lifting the veil of God's revelation in our culture. We are lifting the veil to see God, to see Christ in ourselves and our culture. In so doing, we are connecting with peoples in every culture. For Aboriginal people, Christ was behind a curtain. Some were able to see Christ through a small gap in that curtain. We now need the courage to push our heads through the curtain so that we really can see God in Christ, in our own culture, in our own world, where we are. (p. 7)

Dowling's 2001 portrait of her great grandmother 'Mary' painfully recalls the ways in which photographs of Aboriginal people were commonly used as propaganda for assimilation (see Croft 1997:21). Mary was considered to be 'the poster child for Catholic assimilation' and, as such, her photograph had been taken every few months as 'proof of what an Aboriginal woman could become' (Dowling et al. 2007). At the age of 6, Mary's white father placed her in St Joseph's Orphanage from where she embraced the Catholic Church (she even wanted to become a nun) and tried to disassociate herself from her Aboriginal family. It is a story that reflects the complex emotions of the Stolen Generations who often feel 'a genuine sense of love and gratitude for the white people who raised them' (Read 1999:149), and a grieffilled abandonment of Indigenous language, lore, story and heritage.

For 2 years from 1993, after Mary had had a stroke, Dowling cared for her great grandmother. It was during this time that she heard and absorbed the stories about assimilation from visiting elders, a theme that would then dominate her work. Assimilation, for Dowling, meant learning to hide her Aboriginality. She recalls a time in her own life when 'the pressure to assimilate into Wudjula [white] society

5.The notebook that includes this sketch is currently in the British Library, Add MS 9345 f14v. See British Library, 'Sydney Parkinson's sketchbook', viewed 29 April 9345 f14v. See British Library, 'Sydney Parkinson's sketchbook', viewed 29 Ap
2019, from https://www.bl.uk/collection-items/sydney-parkinsons-sketchbook. was intense. The value of our identity', she writes, 'was almost crushed by successive government policies and racist interpretations by the Catholic Church' (Dowling 2006:2). Her response was to learn to keep her Aboriginal ways secret (Ryan 1998:45). It is only after she left high school that she has been able to seek out those aspects of [her] own indigenous enlightenment - an enlightenment that was severely damaged by [her] family's dispossession and assimilation' (Dowling 2006:3). Dowling now considers herself to be a 'litmus test' for race relations in Australia (Dowling et al. 2007), one who can draw upon the rich multiplicity of her heritage to rewrite 'the self and the social' reality that is an enduring feature of the national landscape and that resists assimilationist ideologies (ReedDanahay 1997:4).

In Dowling's 'Mary' (2001), it may not be immediately obvious what the connection is between this painting of her great grandmother and the quest for an Australian Jesus, or how this so-called 'transitional figure' of Mary stands at 'the junction of traditional Aboriginal law and "white-fella" ways' (Crumlin 2011:154). One inspiration for this work, however, was Bartolomé Esteban Perez Murillo's ‘Esquilache Immaculate Conception' (1645-55), which hangs today in the Hermitage Museum in Saint Petersburg. Murillo's Mary is characteristic of so much Christian art and its lingering debt to Neoplatonism, thanks in no small part to St Augustine. It is, in many ways, a most unfortunate debt, for it finds expression in a tendency to keep separate things of the earth from the things of heaven so that the latter are never really at home in the former. In my judgement, however, it is Dowling rather than Murillo who does a better job at placing, and bearing witness to, the unashamedly earthed realities of the Christian faith born of the Incarnation.

\section{Conclusion: Whose image is the Christ?}

The examples offered above raise many interesting questions: What happens to religious images and symbols when they get employed outside of their traditional contexts and charged with unapproved and heterodox interpretations? Who owns such images? Do religious believers and institutions maintain veto on the use of such images, or do they belong to no one, and so to all? Whose image is the Christ?

Some artists view religion as little or nothing more than a quaint (at best) or malevolent (at worst) social phenomenon. For others, religion and religious images furnish us with narratives, space, language - permission even - to raise larger issues that affect us all. Still others look to religion as a means by which meaning-making can occur. We live by the stories, the myths, we tell ourselves. Even for non-believers, religious symbols and stories can provide 'a larger narrative for our fragmented and information-saturated lives'. This 'fascination with religious themes suggests a longing for 6.I draw here upon notes from a public lecture given by Chaplin (2013). 
repeated and repeatable points of orientation for the meaningful ordering of our lives - liturgical punctuations in an otherwise fluid existence' (Chaplin 2013). Some artists attend to or return to religious themes, including images of Jesus, because such themes mediate opportunities to revisit childhood faith and to explore the possibilities of connecting to current experiences of being-in-the-world. To repeat: We live by the stories, the myths, we tell ourselves. Mostly, those stories and myths are carried and passed on as fragments, and many such are religious in nature, the images and symbols we carry - and which carry us - but which are often entombed and embrangled in the penetralia of our common cultural anima. As Box Saxton, a character in the New Zealand writer Carl Nixon's novel, Settlers' Creek, blurts out when overcome by a moment of unwitting anamnesis borne from seeing an image from the Bible: 'That was all those years of Sunday school talking. You could never put that imagery behind you, no matter how hard you didn't believe' (Nixon 2010:93). Or as Nick Cave describes his own experience of discovering the Bible: 'I found the stories of the Bible calling to me from somewhere in my subconscious, planted there in the choirboy days in my childhood' (Cave 2000). I wonder how and if future generations not experienced with religious practices will know this same possibility. Here, the Spirit, God's own liveliness, is perhaps the only hope.

Wilson Yates is among a growing number of voices reminding us that religious communities, especially those whose face is turned towards the world, cannot contain the symbols and images birthed in their midst. Rather, they become:

[A] part of the culture and life far beyond the final control of the church, ... imaged in diverse ways by non-Christian as well as Christian artists, often contrary to the church's dominant interpretation. (Yates 2000:4)

'But', he continues, 'this should not be viewed as threatening', but rather as 'a means by which, paradoxically, the traditional symbols are kept vital - are kept alive in the midst of human life' (Yates 2000:4). We might say that they become new invitations to, as it were, see the world again. Such engagements might even be more than a capitulation to contemporary efforts at enchantment. Indeed, they might be nothing short of an expression of God's own life. Herein lies the possibility of seeing Jesus as more (although never less) than 'a pretty decent sort of bloke' - as anima mundi, as the world's soul in whom is given the possibility to live and to construct meaning.

There is a deep uncertainty present in every act of creation. If we are lucky, the quest for an Australian Jesus is met by one who remains elusive and uninhibited, who gives himself to people and to cultures but repudiates being domesticated by any one of them or being homogenised into the god of any God-botherer's tribe - Jesus is no Christian. It is met by one who in 'his own strange way' (Uniting Church in Australia 1992:22) is present on the open road and calls us both to dialogue 'without superiority, preconceptions, hidden motives or convictions'
(Rowe 1993:160; cf. Carroll 1998; 2001:1-18) and to move away from our puny egos and metaphysical guesswork, before disappearing again. There is a deep uncertainty present in every act of creation. It can cause us to doubt our own assumptions. And sometimes our hearts burn within us as we make our way (Anonymous 1986):

'Vergiss du nie', 7 the voice beside me said,

Smelting the words into my silent mind

Made silent by the silence at my side. (p. 215)

\section{Acknowledgements}

The author is grateful to Terry Falla, Rod Pattenden, Frank Rees and Naomi Wolfe for sharpening his thinking on this topic.

\section{Competing interests}

The author has declared that no competing interests exist.

\section{Author(s)contributions}

I declare that I am the sole author of this article.

\section{Ethical consideration}

This article followed all ethical standards for a research without direct contact with human or animal subjects.

\section{Funding information}

This research received no specific grant from any funding agency in the public, commercial or not-for-profit sectors.

\section{Data availability statement}

Data sharing is not applicable to this article as no new data were created or analysed in this study.

\section{Disclaimer}

The views and opinions expressed in this article are those of the author and do not necessarily reflect the official policy or position of any affiliated agency of the author.

\section{References}

Anonymous, 1986, 'The promise', in A. Les Murray (ed.), Anthology of Australian religious poetry, pp. 215-220, Collins Dove, Melbourne.

Banks, J., 1962, The Endeavour Journal of Joseph Banks 1768-1771, vol. 2, The Trustees of the Public Library of New South Wales in association with Angus and Robertson, Sydney.

Bannister, J. \& Dowling, J., 2005, Julie Dowling interviewed by John Bannister, audio recording, J.S. Battye Library of West Australian History, National Library of Australia, Canberra.

Bartlett, T., 2004, 'The resurrection of Nick Cave', Salon, viewed 12 February 2019, from https://www.salon.com/2004/11/18/cave_4/.

Berndt, R.M., 1948, 'A 'WDnguri-'Mandzikai song cycle of the Moon-Bone', Oceania 19(1), 16-50. https://doi.org/10.1002/j.1834-4461.1948.tb00493.x

Bonhoeffer, D., 2010, Letters and papers from prison, transl. J. de Gruchy et al., Fortress Press, Minneapolis.

Brady, E.J., n.d., Unpublished papers, MSS A3173-A3176-2, Mitchell Library, State Library of New South Wales, Sydney.

7.Don't ever forget. 
British Library, 1770, Sydney Parkinson's sketchbook, viewed 29 April 2019, from https://www.bl.uk/collection-items/sydney-parkinsons-sketchbook.

Carroll, J., 1998, Ego and soul: The modern west in search of meaning, HarperCollins, Sydney.

Carroll, J., 2001, The Western dreaming: The Western world is dying for want of a story, HarperCollins, Sydney.

Cave, N., 2000, The secret life of the love song and the flesh made word: Two lectures by Nick Cave, audio CD, King Mob, London.

Chaplin, A.D., 2013, 'The return of religion in contemporary art', public lecture at the University of Otago, Dunedin, 22 August 2013.

Clark, M., 1990, The quest for grace, Viking, Ringwood.

Cocker, J. \& Cave, N., 2010, 'Nick Cave ribs Jarvis about his radio voice', BBC Radio 6 viewed 12 February 2019, from https://www.bbc.co.uk/programmes/b00tqjr4.

Croft, B.L., 1997, 'Laying ghosts to rest', in J. Annear (ed.), Portraits of Oceania, pp. 8-14, Art Gallery of New South Wales, Sydney.

Crumlin, R., 2011, The Blake book: Art, religion and spirituality in Australia: Celebrating 60 years of the Blake Prize, Macmillan, South Yarra.

Daley, P., 2017, 'It's 50 years since Indigenous Australians first "counted". Why has so little changed?', The Guardian, viewed 19 May 2017, from https://www. theguardian.com/inequality/2017/may/18/50-years-since-indigenous-australiansfirst-counted-why-has-so-little-changed-1967-referendum.

Daley, V., 1947, 'The sorrowful one', in M. Holburn \& M. Pizer (eds.), Creeve Roe, p. 78 Pinchgut Press, Sydney.

Dodson, P.L., 1988, 'The land our mother, the Church our mother', in P. Malone (ed.), Discovering an Australian theology, pp. 83-88, St Pauls Publications, Homebush.

Dowling, J., 2006, 'Occasional address: Ms Julie Dowling', Murdoch University, Perth, viewed 27 March 2006, from http://our.murdoch.edu.au/University-SecretarysOffice/_document/University-History/Graduation-speeches/Occasional-2006 Julie-Dowling.pdf.

Dowling, J., Ross, K.J. \& Browning, D., 2007, Julie Dowling: Strange fruit, audio recording, $A B C$ Radio National, viewed 28 July 2007, from http://www.abc.net. au/radionational/programs/awaye/julie-dowling-strange-fruit/3669390.

Eaglestone, R., 2009, 'From mutiny to calling upon the author: Cave's religion', in K. Welberry \& T. Dalziell (eds.), Cultural seeds: Essays on the work of Nick Cave, pp. 139-151, Ashgate, Farnham.

Fortescue, E., 2015, 'Art: Portrait of a suffering artist', The Daily Telegraph, viewed 15 September 2015, from https://www.dailytelegraph.com.au/art-portrait-of-asuffering-artist/news-story/6ec5c00bcf532c96e2dc49c7ba0ee7e2

Gill, A., 1984, 'Draft rule of the community', House of the Gentle Bunyip collection, Whitley College, Parkville.

Gill, A., 1990, The fringes of freedom: Following Jesus, living together, working for Justice, Lancer/Anzea, Homebush West.

Gill, A., 1993, Life on the road: The gospel basis for a messianic lifestyle, Herald Press, Scottdale.

Hill, B., 2002, Broken song: T.G.H. Strehlow and Aboriginal possession, Alfred A. Knopf, Sydney.

Jackett, A.E., 2013, 'Imagined portraits: Reviving figures from Australia's past', PhD thesis, University of Tasmania.

Jensen, E., 2014, Acute misfortune: The life and death of Adam Cullen, Black Inc., Collingwood.

Johnston, I., 1996, Bad seed: The biography of Nick Cave, Abacus, London.

Kramer, L., 1974, 'The tree of man: An essay in Scepticism', in W.S. Ramson (ed.), The Australian experience: Critical essays on Australian novels, pp. 269-283, Australian National University Press, Canberra.

Lawson, H., 1984, 'In the street', in L. Cronin (ed.), A camp-fire yarn: Henry Lawson, complete works 1885-1900, pp. 406-407, Lansdowne Press, Sydney.

McCredden, L., 2009, 'Fleshed sacred: The carnal theologies of Nick Cave', in K. Welberry \& T. Dalziell (eds.), Cultural seeds: Essays on the work of Nick Cave, pp. 167-185, Ashgate, Farnham.

McGrath, J., 2002, 'Julie Dowling: A different way to the future', Australian Art Collector 19(January-March), 37-40.

Metz, J.B., 1981, The emergent Church: The future of Christianity in a Postbourgeois world, SCM Press, London.
Millikan, D., 1981, The sunburnt soul, Lancer, Sydney.

Mnemba, J.J., 1988, 'African Christology: Images of Christ in Africa', Religion in Malawi 2(1), 30-32.

Nick Cave and the Bad Seeds, 1997, There is a kingdom, audio CD, Mute Records, London.

Nick Cave and the Bad Seeds, 2001, Darker with the day, audio CD, Mute Records, London.

Nick Cave and the Bad Seeds, 2016, 'Jesus alone', Skeleton tree, audio CD, Bad Seed, London.

Nixon, C., 2010, Settlers' creek, Random House, Auckland.

O'Doherty, C., 2018, 'Artist statement', in C. Donarski (ed.), The 65th Blake Prize, pp. 40-41, Casula Powerhouse Arts Centre, Casula.

O'Farrell, P., 1962, 'The history of the New South Wales Labour Movement, 1880-1910. A religious interpretation', The Journal of Religious History 2(2), 133-151. https://doi. org/10.1111/j.1467-9809.1962.tb00790.x

Paterson, A.B., 1905, 'My religion', in The old bush songs: Composed and sung in the bushranging, digging and overlanding days, pp. 127-128, Angus and Robertson, Sydney.

Pattenden, R., 2014, 'Seeing otherwise: Touching sacred things', in J. Havea (ed.) Indigenous Australia and the unfinished business of theology: Cross-cultural engagement, pp. 17-30, Palgrave Macmillan, New York.

Paulson, G., 2006, 'Towards an Aboriginal theology', Pacifica 19(3), 310-320. https:// doi.org/10.1177/1030570X0601900310

Payne, J., 2010, 'Improvisations with Nick Cave', Los Angeles Times, viewed 11 Apri 2019, from https://articles.latimes.com/2010/nov/29/entertainment/la-et-nickcave-20101129.

Perkins, H. \& Lynn, V., 1993, 'Blak artists, cultural activists', in Australian perspecta, pp. $x$-xii, Art Gallery of New South Wales, Sydney.

Piggin, S., 2000, 'Jesus in Australian history and culture', in S. Emilsen \& W.W Emilsen (eds.), Mapping the landscape: Essays in Australian and New Zealand Christianity: Festschrift in honour of Professor lan Breward, pp. 150-167, Peter Lang, New York.

Read, P., 1999, A rape of the soul so profound: The return of the stolen generations, Allen \& Unwin, St Leonards.

Reed-Danahay, D., 1997, Auto/ethnography: Rewriting the self and the social, Bloomsbury Academic, London.

Rees, F.D., 1999, 'Re-cognising the Christ: An Australian response to John Dominic Crossan', Colloquium 31(2), 99-109.

Rowe, N., 1993, 'Are there really angels in Carlton? Australian literature and theology', Pacifica 6(2), 141-64. https://doi.org/10.1177/1030570X9300600203

Ryan, L.S., 1998, 'Grandmother's mob and the stories', Artlink 18(1), 45-47.

Smith, B., 1985, 'The first European depictions', in I. Donaldson \& T. Donaldson (eds.), Seeing the first Australians, pp. 21-34, George Allen \& Unwin, Sydney.

Smith, K.V., 2009, 'Confronting Cook', Electronic British Library Journal, viewed 29 April 2019, from https://www.bl.uk/eblj/2009articles/pdf/ebljarticle42009.pdf.

The Rainbow Spirit Elders, 2012, Rainbow Spirit theology: Toward an Australian Aboriginal theology, ATF Press, Hindmarsh.

Turner, C., 2014, 'Correlation, conversation, contrast: Applications of an Australian contextual theology', PhD thesis, University of Divinity.

Uniting Church in Australia, 1992, The Basis of Union, Uniting Church Press, Melbourne.

Walker, K., 1992, 'Aboriginal charter of rights', in The dawn is at hand: Selected poems, pp. 60-61, Marion Boyars, London.

Watson, M., 1994, 'Memo to J.C.', in K. Hart (ed.), The Oxford book of Australian religious verse, pp. 222-223, Oxford University Press, Melbourne.

White, P., 1956, The tree of man, Jonathan Cape, London.

Yates, W., 2000, 'Conflict and conversations between religion and art: Brooklyn and beyond', ARTS: The Arts in Religious and Theological Studies 12(1), 2-5.

Zaunbrecher, M., 1979, 'Religious attitudes in Australian literature of the 1890s', MA thesis, University of Wollongong.

Zaunbrecher, M., 1980, 'Henry Lawson's religion', Journal of Religious History 11(2), 308-319. https://doi.org/10.1111/j.1467-9809.1980.tb00593.x 